University of Nebraska - Lincoln

DigitalCommons@University of Nebraska - Lincoln

Nitrogen Capture by Grapevine Roots and Arbuscular Mycorrhizal Fungi from Legume Cover-Crop Residues Under Low Rates of Mineral Fertilization

\author{
Xiaomei Cheng \\ Mount St. Mary's College \\ Amy Euliss \\ USDA-ARS
}

Kendra Baumgartner

USDA-ARS

Follow this and additional works at: https://digitalcommons.unl.edu/usdaarsfacpub

Part of the Agricultural Science Commons

\footnotetext{
Cheng, Xiaomei; Euliss, Amy; and Baumgartner, Kendra, "Nitrogen Capture by Grapevine Roots and Arbuscular Mycorrhizal Fungi from Legume Cover-Crop Residues Under Low Rates of Mineral Fertilization" (2008). Publications from USDA-ARS / UNL Faculty. 288.

https://digitalcommons.unl.edu/usdaarsfacpub/288
}

This Article is brought to you for free and open access by the U.S. Department of Agriculture: Agricultural Research Service, Lincoln, Nebraska at DigitalCommons@University of Nebraska - Lincoln. It has been accepted for inclusion in Publications from USDA-ARS / UNL Faculty by an authorized administrator of DigitalCommons@University of Nebraska - Lincoln. 


\title{
Nitrogen capture by grapevine roots and arbuscular mycorrhizal fungi from legume cover-crop residues under low rates of mineral fertilization
}

\author{
Xiaomei Cheng • Amy Euliss • Kendra Baumgartner
}

Received: 19 June 2007 /Revised: 4 March 2008/Accepted: 6 March 2008 /Published online: 2 April 2008

\begin{abstract}
The influence of mineral fertilization on root uptake and arbuscular mycorrhizal fungi-mediated ${ }^{15} \mathrm{~N}$ capture from labeled legume (Medicago polymorpha) residue was examined in winegrapes (Vitis vinifera) in the greenhouse, to evaluate compatibility of fertilization with incorporation of cover-crop residue in winegrape production. Plants grown in marginal vineyard soil were either fertilized with $0.25 \times$ Hoagland's solution or not. This low fertilization rate represents the deficit management approach typical of winegrape production. Access to residue in a separate compartment was controlled to allow mycorrhizal roots (roots + hyphae), hyphae (hyphae-intact), or neither (hyphae-rotated) to proliferate in the residue by means of mesh core treatments. Leaves were weekly analyzed for ${ }^{15} \mathrm{~N}$. On day 42, plants were analyzed for ${ }^{15} \mathrm{~N}$ and biomass; roots were examined for intraradical colonization; and soils were analyzed for ${ }^{15} \mathrm{~N}$, inorganic $\mathrm{N}$, Olsen-P, X-K, and extraradical colonization. As expected, extraradical colonization of soil outside the cores was unaffected by mesh core treatment, while that inside the cores varied significantly. ${ }^{15} \mathrm{~N}$ atom $\%$ excess was highest in leaves of roots + hyphae. In comparison, leaf ${ }^{15} \mathrm{~N}$ atom $\%$ excess in hyphae-intact was consistently intermediate between roots + hyphae and hyphae-rotated, the latter of which remained unchanged over time. Fertilization stimulated host and fungal growth, based on higher biomass and
\end{abstract}

\section{Cheng}

Department of Biological Science, Mount St. Mary's College, Los Angeles, CA 90049, USA

\footnotetext{
A. Euliss $\cdot K$. Baumgartner $(\square)$

Agricultural Research Service, USDA,

One Shields Avenue,

Davis, CA 95616, USA

e-mail: kbaumgartner@ucdavis.edu
}

intraradical colonization of fertilized plants. Fertilization did not affect hyphal or root proliferation in residue but did lower $\% \mathrm{~N}$ derived from residue in leaves and stems by $50 \%$. Our results suggest that even low fertilization rates decrease grapevine $\mathrm{N}$ uptake from legume crop residue by both extraradical hyphae and roots.

Keywords Legume residue $\cdot$ Medicago polymorpha $\cdot{ }^{15} \mathrm{~N}$. Soil fertility $\cdot$ Vitis vinifera

\section{Introduction}

Arbuscular mycorrhizal fungi (AMF) have a primary role in promoting plant growth when soil phosphorus $(\mathrm{P})$ is low (Allen 1991). AMF may also enhance nitrogen (N) acquisition, based on evidence of ${ }^{15} \mathrm{~N}$ uptake from labeled organic matter by the soil-inhabiting component of the fungus, the extraradical hyphae, and subsequent translocation to host plants (Ames et al. 1983; Hawkins et al. 2000; Hodge et al. 2001; Johansen et al. 1992; Mäder et al. 2000). The narrow width and the abundance of the extraradical hyphae make them uniquely adapted to proliferate within soil organic matter (St John et al. 1983) and absorb inorganic $\mathrm{N}\left(\mathrm{NH}_{4}^{+}, \mathrm{NO}_{3}^{-}\right)$, which is assimilated into amino acids for transfer to the host (Jin et al. 2005).

The proportion of host $\mathrm{N}$ attributed to uptake by extraradical hyphae varies from $0.2 \%$ to $50 \%$ in several studies (Ames et al. 1983; Hawkins and George 1999; Hawkins et al. 2000; Johansen et al. 1994). Among the many factors that alter the impact of AMF on $\mathrm{N}$ acquisition is the content of main nutrients in the soil (Johnson et al. 2003; Treseder and Allen 2002). In low fertility soil, slight increases in soil $\mathrm{N}$ or $\mathrm{P}$ with low rates of fertilization have been shown to benefit both the host and fungus (Hawkins 
and George 1999; Hawkins et al. 2000; Johansen et al. 1994; Mäder et al. 2000). High rates of fertilization, in contrast, benefit only the host, as carbon (C) allocation to the fungus decreases when $\mathrm{N}$ or $\mathrm{P}$ availability to the roots is sufficient for maximum host growth (Olsson et al. 2005).

Soil fertility is typically modified by mineral fertilizers or by incorporation of organic matter, such as manure or legume crop residues. Mineral fertilizers are, generally, known to limit AMF (Treseder 2004). Manure and crop residues, in contrast, have been shown to benefit AMF (Gryndler et al. 2006; Schreiner and Bethlenfalvay 2003). Reports of both positive (Hawkins and George 1999) and negative (Mäder et al. 2000) effects of mineral fertilization on hyphal capture of ${ }^{15} \mathrm{~N}$ from labeled $\mathrm{NH}_{4} \mathrm{NO}_{3}$ solution suggest that the combined effects of mineral fertilization and addition of organic matter on AMF-mediated $\mathrm{N}$ acquisition are difficult to predict. Such information is, nonetheless, crucial for growers transitioning to more sustainable farming practices, as soil microbial processes regulate nutrient availability from organic matter inputs.

Past research suggests that mineral fertilization decreases AMF colonization (Treseder 2004), but such studies were carried out in cropping systems typified by high rates of fertilization and focused on synthetic fertilizers as the means of increasing the main nutrient content in the soil. In cropping systems where synthetic fertilizers are used together with legume crop residues, there is a need to determine if mineral fertilization affects AMF-mediated $\mathrm{N}$ acquisition from crop residue. Winegrape (Vitis vinifera $\mathrm{L}$.) production is one such cropping system in which a combination of mineral fertilization and cover cropping are typically used to manipulate soil nutrient content. In addition, inputs from mineral fertilizers are relatively low compared to that of annual cropping systems, as maximizing yield is not the goal of winegrape production. Nitrogen input is minimized to limit shoot growth (Perret et al. 1983), and water stress is imposed to decrease fruit cluster weight, thereby enhancing wine composition through increased surface area of the fruit skin relative to berry size (Matthews et al. 1990). Fertilizers are typically applied to intrarow soil through the drip-irrigation system. The portion of the vineyard floor in between the intrarows, the interrows, is planted with the cover crop.

Vineyard soils support indigenous AMF (Cheng and Baumgartner 2004b; Deal et al. 1971; Menge et al. 1983; Nappi et al. 1985; Oehl et al. 2005; Possingham and GrootObbink 1971). Grapevines respond positively to AMF, as evidenced by increased growth with inoculation (Biricolti et al. 1997; Linderman and Davis 2001; Schubert et al. 1988). Furthermore, their low root density (Schreiner 2005) and coarse root texture suggest that the mycorrhizal dependency of grapevines is relatively high (Eissenstat 1992). Grapevine roots utilize $\mathrm{N}$ from legume crop residue tilled into vineyard soil (Patrick et al. 2004; Patrick-King and Berry 2005), but vine root densities may be low in soil where residues are incorporated (Schreiner 2005) because cover crops are typically planted up to $1 \mathrm{~m}$ away from the vines (Ingels et al. 2005). Therefore, it is possible that root-distant hyphae have access to $\mathrm{N}$ from crop residue that is spatially unavailable to roots, and this arrangement may be important for grapevine $\mathrm{N}$ acquisition (Hawkins et al. 2000).

To determine the compatibility of mineral fertilization with incorporation of legume crop residue, in terms of AMF-mediated $\mathrm{N}$ capture, we grew mycorrhizal grapevines in a marginal vineyard soil and treated half of the plants with a low concentration of N-P-K fertilizer, as is typical of the deficit management approach used in winegrape production to purposely limit grapevine shoot growth and, thus, enhance fruit composition. This is in contrast to the high rates of mineral fertilization common in annual cropping systems, where negative effects of fertilization on AMF have been demonstrated (Treseder 2004).

\section{Materials and methods}

\section{Experimental design}

This greenhouse experiment was conducted on mycorrhizal plants grown in containers $(20 \mathrm{~cm}$ diameter $\times 25 \mathrm{~cm}$ depth; $7,850 \mathrm{~cm}^{3}$ volume) within which a polyvinyl chloride (PVC) mesh core was vertically inserted, as shown in Fig. 1, using a container design similar to that of a previous study (Cheng and Baumgartner 2006). Mesh cores were constructed by cutting four windows into a $25-\mathrm{cm}$ long section of PVC pipe $(6.8 \mathrm{~cm}$ inner diameter, $7.2 \mathrm{~cm}$ outer diameter; $907.5 \mathrm{~cm}^{3}$ volume). Inner and outer pipe surfaces were wrapped with either $1-\mathrm{mm}$ plastic mesh or $25-\mu \mathrm{m}$ stainless steel mesh. To create an air gap that minimized mass flow of soil solution (and ${ }^{15} \mathrm{~N}$ ) from inside the mesh core, a piece of 2 -mm-thick plastic mesh $\left(8 \times 7 \mathrm{~cm}^{2}\right)$ was inserted at each window between the two mesh layers. Core bottoms were covered with 1-mm plastic mesh.

At the time of planting, a mesh core was vertically inserted inside each container and filled with growth medium. A very narrow PVC pipe $(2.1 \mathrm{~cm}$ diameter $\times$ $25 \mathrm{~cm}$ length) was vertically inserted into the center of each mesh core, to a depth of $20 \mathrm{~cm}$, to reserve a column of space for the eventual addition of labeled legume residue. To control root and hyphal access to labeled legume residue, there were three mesh core treatments: 1-mm plastic mesh to allow fine roots and hyphae to penetrate the mesh core (roots + hyphae), $25-\mu \mathrm{m}$ stainless steel mesh to allow only hyphae (hyphae-intact), and $25-\mu \mathrm{m}$ stainless steel mesh to exclude roots, plus rotation of the mesh core within the containers every other day to exclude hyphae 


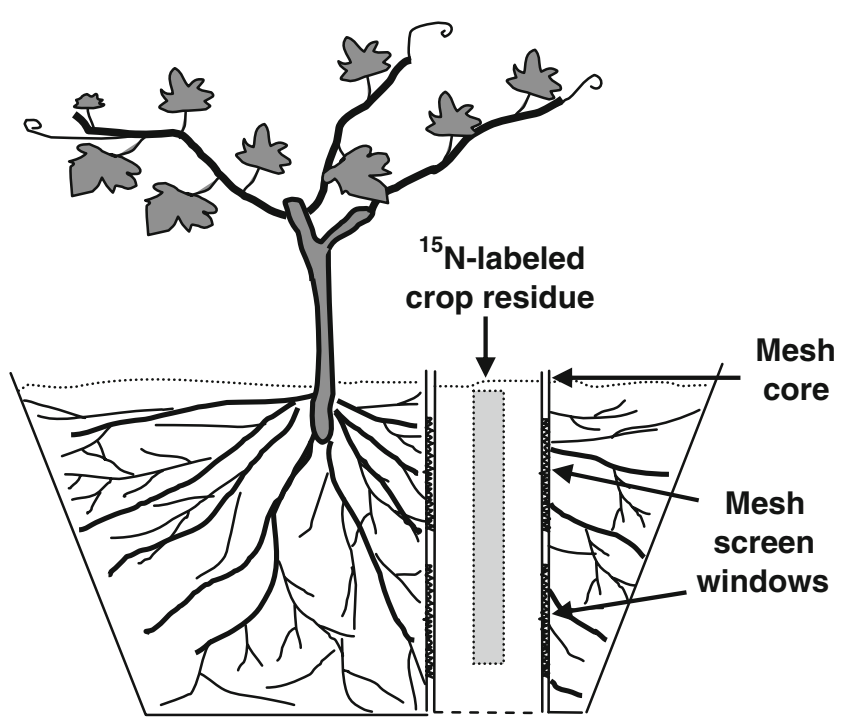

Fig. 1 Side view of grapevine growing in a specially designed container, within which a cylindric mesh core was vertically inserted. Mesh screen windows of variable pore diameter, $1 \mathrm{~mm}$ or $25 \mu \mathrm{m}$, allowed roots and extraradical hyphae ('roots + hyphae' treatment) or only hyphae ('hyphae-intact' treatment) to proliferate in ${ }^{15} \mathrm{~N}$-labeled crop residue that was added to the center of the core after the mesh cores were in place for a total of 4 months. A third set of cores wrapped with $25-\mu \mathrm{m}$ mesh screen was rotated to prevent hyphae from proliferating in the residue ('hyphae-rotated' treatment)

(hyphae-rotated). Treatments were arranged in a completely randomized design, and the experiment was carried out for one growing season in the greenhouse, for a total of 5.5 months. The timeline for the experiment was as follows: grapevines were grown in containers with the mesh core treatments in place from months 1 to 5.5 , fertilization treatments imposed from months 2 to 5.5, labeled material was added to the mesh cores in month 4 , and kept in place from months 4 to 5.5 .

Plants were $V$. vinifera cv. Cabernet Sauvignon (ENTAV clone 338), grafted onto 110R rootstock ( $V$. berlandieri Planch. $\times V$. rupestris Scheele). Grafted, dormant cuttings of the scion and rootstock were first rooted in the field at a commercial grapevine nursery from March to November, harvested from the soil in December, then rooted in our greenhouse the following March. Growth medium for the containers shown in Fig. 1 consisted of a 1:1 $(v / v)$ mixture of field soil from a winegrape vineyard in Napa, CA, USA and sterile sand $\left(0.7 \mathrm{mg} \mathrm{g}^{-1}\right.$ of total $\mathrm{N}, 38 \mu \mathrm{g} \mathrm{g}^{-1}$ of Olsen$\mathrm{P}, 4 \mu \mathrm{mol} \mathrm{\textrm {g } ^ { - 1 }}$ of X-K, $102 \mu \mathrm{mol} \mathrm{g} \mathrm{g}^{-1}$ of cation exchange capacity). Although dormant roots of field-propagated vines contain AMF propagules (Cheng and Baumgartner 2004b), we also added chopped fine roots and rhizosphere soil as an added source of inoculum from the same vineyard we obtained field soil, to ensure colonization. Grapevine roots (up to $2 \mathrm{~mm}$ in diameter) and the soil adhering to the root surface were collected with a hand trowel from the upper $15 \mathrm{~cm}$ of soil, within a $0.3-\mathrm{m}$ radius of the base of the vine, from a total of 30 vines. Roots were brought back to the laboratory, chopped coarsely into segments approximately $1 \mathrm{~cm}$ in length, mixed, separated into $10-\mathrm{g}$ aliquots (approximately $100 \mathrm{ml}$ in volume), and immediately incorporated into the top $10 \mathrm{~cm}$ of growth medium per plant, both inside and outside the mesh cores 1 day after planting.

\section{Mineral fertilization}

Starting 2 months after planting, half of the plants (four per mesh core treatment) were fertilized on a weekly basis with $0.25 \mathrm{X}$ Hoagland's solution, containing $50.8 \mathrm{mg} \mathrm{N}^{-1}$ as $\mathrm{KNO}_{3}$ and $\mathrm{Ca}\left(\mathrm{NO}_{3}\right)_{2}, 7.5 \mathrm{mg} \mathrm{P} l^{-1}$ as $\mathrm{KH}_{2} \mathrm{PO}_{4}$, and $55.5 \mathrm{mg} \mathrm{K} l^{-1}$ as $\mathrm{KNO}_{3}$ and $\mathrm{KH}_{2} \mathrm{PO}_{4}$ (Epstein 1972). We previously found this low rate of Hoagland's solution to enhance mycorrhizal colonization of grapevines in the greenhouse (Cheng and Baumgartner 2004a). Fertilizer (1 1 per plant) was applied both inside and outside the mesh cores proportionate to their volumes. Nonfertilized plants received water (1 1 per plant). Over the 5.5 months of the experiment, fertilized plants received a total of $711 \mathrm{mg}$ $\mathrm{N}$ as $\mathrm{KNO}_{3}$ and $\mathrm{Ca}\left(\mathrm{NO}_{3}\right)_{2}$, and $180 \mathrm{mg} \mathrm{N}$ from the legume residue. Nonfertilized plants received only $180 \mathrm{mg} \mathrm{N}$ from the legume residue.

${ }^{15} \mathrm{~N}$-Labeled legume residue

The legume crop, Medicago polymorpha L. cv. Santiago (burr medic), was grown apart from the grapevines, in separate containers with potting mix consisting of $1: 1: 1$ $(v / v / v)$ peat moss, perlite, and Supersoil ${ }^{\circledR}(\operatorname{Rod}$ McClellan Co., South San Francisco, CA, USA). After 4 weeks, plants were watered weekly with $16 \mathrm{mM} \mathrm{K} \mathrm{K}^{15} \mathrm{NO}_{3}$ for four additional weeks. Shoots were harvested, oven-dried, finely ground, and analyzed for ${ }^{15} \mathrm{~N}$ with a mass spectrometer (Stable Isotope Facility, University of California, Davis, CA, USA). The dried shoots contained $4.5 \%$ total $\mathrm{N}$ and 5.05 atom $\%$ excess of ${ }^{15} \mathrm{~N}$. The legume residue $(\mathrm{C} / \mathrm{N}$ ratio of $12.17,4.3$ atom $\%$ excess) that was added to each mesh core after 4 months of grapevine growth consisted of $4 \mathrm{~g}$ ground shoots and $70 \mathrm{~g}$ of the growth medium. The narrow PVC pipe was removed from the center of the mesh core and residue was carefully poured into the empty column, creating a $20-\mathrm{cm}$ long cylindrical column of labeled legume residue at the center of the mesh core. Approximately $20 \mathrm{ml}$ water was applied to the mesh cores to moisten the residue.

Plant and soil analyses

After adding the residue to the cores, two leaves per plant were harvested on days $0,7,14,21,28$, and 35 . On day 42 , 
Table 1 Summary of ANOVA results for mycorrhizal grapevines grown in containers with three mesh core treatments (hyphae-rotated, hyphae-intact, roots + hyphae), with or without fertilization

\begin{tabular}{|c|c|c|c|}
\hline \multirow[t]{2}{*}{ Variable } & \multicolumn{3}{|l|}{$F$ values } \\
\hline & Fertilization & Fertilization $\times$ mesh core & Mesh core \\
\hline \multicolumn{4}{|c|}{ AMF colonization } \\
\hline Intraradical & $5.8^{*}$ & 1.0 & 0.3 \\
\hline \multicolumn{4}{|c|}{ Plant growth and $\mathrm{N}$ status } \\
\hline \multicolumn{4}{|l|}{ Biomass } \\
\hline Leaf & $16.9 *$ & 0.5 & 3.5 \\
\hline Stem & 2.0 & 1.5 & 2.0 \\
\hline Root & $49.9 * *$ & 0.7 & 0.8 \\
\hline \multicolumn{4}{|l|}{ Total N } \\
\hline Leaf & $24.5^{* *}$ & 0.3 & $17.0^{* *}$ \\
\hline Stem & 2.0 & 1.3 & 2.8 \\
\hline Root & $15.2 *$ & 0.6 & 0.6 \\
\hline \multicolumn{4}{|c|}{${ }^{15} \mathrm{~N}$ atom $\%$ excess } \\
\hline Leaf & $36.0 * *$ & $4.6^{*}$ & $28.7 * *$ \\
\hline Stem & $42.6^{* *}$ & $13.8^{*}$ & $61.3 * *$ \\
\hline Root & 3.8 & 2.2 & 2.4 \\
\hline \multicolumn{4}{|l|}{ Total ${ }^{15} \mathrm{~N}$} \\
\hline Leaf & $20.4^{*}$ & 3.2 & $68.0 * *$ \\
\hline Stem & $15.8^{*}$ & $12.8^{*}$ & $61.9^{* *}$ \\
\hline Root & 1.4 & 1.8 & 2.9 \\
\hline \multicolumn{4}{|l|}{$\%$ NDFL } \\
\hline Leaf & $50.4^{* *}$ & 2.8 & $41.6^{* *}$ \\
\hline Stem & $42.6^{* *}$ & $13.8^{*}$ & $61.2 * *$ \\
\hline Root & 3.8 & 2.2 & 2.5 \\
\hline
\end{tabular}

$\%$ NDFL Percentage $\mathrm{N}$ in plant tissues derived from the legume residue

$* p \leq 0.05, * * p \leq 0.0001$

plants were harvested for determination of biomass and ${ }^{15} \mathrm{~N}$ content of the leaves, stems, and roots and intraradical colonization of roots. Leaves, stems, and roots were dried $\left(70^{\circ} \mathrm{C}\right.$ for 7 days), weighed, and analyzed for total $\mathrm{N}$ and ${ }^{15} \mathrm{~N}$. Nitrogen uptake from the residue was estimated based on the assumption that equal proportions of labeled and nonlabeled $\mathrm{N}$ were captured by roots and/or hyphae and translocated to the host. Percentage $\mathrm{N}$ in plant tissues derived from the legume residue (\%NDFL) was calculated using the following formula

$$
\begin{aligned}
\% \mathrm{NDFL}= & \left(\operatorname{total}^{15} \mathrm{~N}_{\text {grapevine }} / \text { total }{ }^{15} \mathrm{~N}_{\text {legume residue }}\right) \\
& \times \text { total } \mathrm{N}_{\text {legume residue }} \times 100 / \mathrm{N}_{\text {grapevine }}
\end{aligned}
$$

where total ${ }^{15} \mathrm{~N}$ of legume residue is $9.09 \mathrm{mg}$ and total $\mathrm{N}$ of legume residue is $180 \mathrm{mg}$.

Roots that grew outside the mesh cores of all treatments were stained (Koske and Gemma 1989). Intraradical colonization (percentage of root length) was estimated from $0.75 \mathrm{~g}$ fresh roots per plant by the gridline intersect method using a dissecting microscope at $\times 10$ magnification (Giovannetti and Mosse 1980). Intraradical colonization was expressed as the percentage of the 100 intersects examined where AMF structures were present, for an average of three grid rearrangements per sample. Intraradical colonization per 100 intersects was adjusted for percent root length, as estimated from 100 intersect counts (Newman 1966). Roots that grew inside the mesh cores of the roots + hyphae treatment were manually picked from the soil, dried $\left(70^{\circ} \mathrm{C}\right.$ for 7 days), and weighed.

On day 42, soil from outside and inside the mesh cores was collected and homogenized separately, dried $\left(70^{\circ} \mathrm{C}\right.$ for 7 days), ground, and analyzed for ${ }^{15} \mathrm{~N}$, Olsen-P, and XK (DANR Laboratories, University of California, Davis, CA, USA). A subset of soils was placed on ice, then transferred to $-20^{\circ} \mathrm{C}$ until inorganic $\mathrm{N}$ was extracted with $2 \mathrm{M} \mathrm{KCl}$, and analyzed for $\mathrm{NH}_{4}^{+}-\mathrm{N}$ and $\mathrm{NO}_{3}^{-}-\mathrm{N}$. Extraradical hyphae were extracted from six 5-g (fresh weight) soil subsamples per plant, three from outside and three from inside the cores, by an aqueous membrane filtration method (Boddington et al. 1999; Jakobsen et al. 1992; Miller et al. 1995). When the extracted hyphae were viewed at $\times 200$ magnification with a compound microscope, hyphal intersections for every other vertical and horizontal line, a total of ten lines on a $0.5-\mathrm{mm}$ grid, were counted for 50 fields of view (FOVs). To exclude saprophytic fungi, we tallied only coenocytic hyphae. Fresh weight to dry weight conversions were determined for the 5-g soil sample. Extraradical hyphal length, $R$, was calculated from FOVs averaged across subsamples with the following formula (Newman 1966)

$R=(\pi \mathrm{A} \times n / 2 H) \times(\mathrm{FA} / \mathrm{A})$

where $\mathrm{A}$ is the reticle area $\left(0.25 \mathrm{~mm}^{2}\right), n$ is the number of intersects, $\mathrm{H}$ is the total line length (ten lines $\times 0.5 \mathrm{~mm}$ per line $=5 \mathrm{~mm})$, and FA is the filter area $\left(200.96 \mathrm{~mm}^{2}\right)$.

\section{Statistical analyses}

Data were analyzed using the MIXED procedure in Statistical Analysis System (SAS System, version 8.2, SAS Institute, Cary, NC, USA). A three-way analysis of variance (ANOVA) was used to examine the effects of mesh core treatment, fertilization, and time on ${ }^{15} \mathrm{~N}$ atom $\%$ excess in leaves collected weekly after adding labeled residue to the cores. Time was treated as a repeated measure. Two-way ANOVAs were used to examine the effects of mesh core treatment and fertilization on ${ }^{15} \mathrm{~N}$ atom $\%$ excess, total ${ }^{15} \mathrm{~N}, \% \mathrm{NDFL}$, total $\mathrm{N}$, and biomass of leaves, shoots, and roots collected at the end of the experiment. Two-way ANOVAs were also used to examine the effects of mesh core treatment and fertilization on soil ${ }^{15} \mathrm{~N}$, legume residue ${ }^{15} \mathrm{~N}$, and intraradical colonization of roots. For variables gathered from the soil (extraradical colonization, inorganic $\mathrm{N}$, Olsen-P, X-K), three-way 
ANOVAs were used to examine the effects of mesh core treatment, fertilization, and soil location (inside versus outside the mesh cores). All factors in all ANOVAs were treated as fixed effects. To satisfy the assumption of homogeneity of variance, the following transformations were applied: a $\log _{10}$ transformation to leaf ${ }^{15} \mathrm{~N}$ atom\% excess (weekly measurements); square root transformations to leaf and root total ${ }^{15} \mathrm{~N}$, leaf \%NDFL, and extraradical colonization; and rank transformations to soil $\mathrm{NH}_{4}^{+}-\mathrm{N}$ and $\mathrm{NO}_{3}^{-}-\mathrm{N}$. For significant effects $(p \leq 0.05)$, treatment means were compared by Tukey's tests. Reverse-transformed means and $95 \%$ confidence limits are presented for data that were transformed prior to ANOVA.

\section{Results}

Plant and fungal responses to fertilization

The growth response of the plants to fertilization was positive. Leaves and roots of fertilized plants had significantly higher biomass and total $\mathrm{N}$ compared to those of nonfertilized plants (Tables 1 and 2). The fungal growth response to fertilization was also positive. Fertilized plants had significantly higher intraradical colonization (Table 2), and this was consistent among all mesh core treatments, as evidenced by no significant mesh core treatment effect on intraradical colonization (Table 1). Although fertilized plants had higher intraradical colonization of their roots, fertilization had no effect on extraradical colonization of the soil $(p=0.1$; Table 2). Despite the fact that fertilization significantly

Table 2 AMF and plant responses to fertilization

\begin{tabular}{lcc}
\hline Variable & $\begin{array}{l}\text { Fertilized } \\
\text { plants }\end{array}$ & $\begin{array}{l}\text { Nonfertilized } \\
\text { plants }\end{array}$ \\
\hline AMF colonization & & \\
$\quad$ Extraradical (m hyphae ${ }^{-1}$ soil) & $3.67 \mathrm{a}$ & $3.36 \mathrm{a}$ \\
Intraradical (\% root length) & $34.91 \mathrm{a}$ & $28.23 \mathrm{~b}$ \\
Plant growth and N status & & \\
Biomass (g plant ${ }^{-1}$ ) & & \\
Leaf & $7.12 \mathrm{a}$ & $5.34 \mathrm{~b}$ \\
Stem & $39.43 \mathrm{a}$ & $34.84 \mathrm{a}$ \\
$\quad$ Root & $29.56 \mathrm{a}$ & $18.67 \mathrm{~b}$ \\
Total N (mg plant & \\
Leaf & & \\
Stem & $62.98 \mathrm{a}$ & $46.07 \mathrm{~b}$ \\
Root & $156.68 \mathrm{a}$ & $139.63 \mathrm{a}$ \\
\hline
\end{tabular}

Means ( $n=24$ for extraradical colonization, $n=12$ for all other variables) followed by different letters in the same row are significantly different at $p \leq 0.05$, Tukey's test. Extraradical colonization was measured from soil samples collected from both inside and outside the mesh cores; intraradical colonization and all plant variables were measured from plant tissues collected from outside the cores increased root biomass outside all mesh core treatments (Table 2), root biomass inside the roots + hyphae cores was not significantly affected by fertilization $(1.58 \mathrm{~g}$ averaged across fertilized and nonfertilized plants, $n=8, p=0.6$ ).

Root and hyphal proliferation inside the mesh cores

Extraradical colonization varied significantly in soil inside the cores but was unaffected by mesh core treatment in soil outside the cores (location $\times$ mesh core treatment effect of $p<0.0001)$. Roots + hyphae cores contained approximately twofold higher concentrations of extraradical hyphae than both hyphae-intact cores and hyphae-rotated cores (Fig. 2). Extraradical hyphal concentrations in hyphae-intact cores and hyphae-rotated cores were not significantly different, demonstrating that frequent rotations did not prevent hyphal proliferation in the residue of the latter treatment. Roots were absent from the hyphae-intact and hyphaerotated cores, as expected. Root density inside roots + hyphae cores was only half that of root density outside

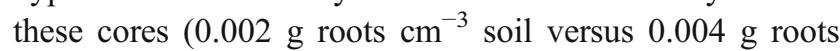
$\mathrm{cm}^{-3}$ soil, respectively, $n=8$ ).

${ }^{15} \mathrm{~N}$ in grapevine tissues

Although fertilization had positive effects on some plant and fungal variables, it was associated with reductions in root and hyphal uptake of ${ }^{15} \mathrm{~N}$ (Fig. 3). A significant mesh core treatment $\times$ fertilization $\times$ time interaction $(p<0.0001)$ signified different temporal trends in ${ }^{15} \mathrm{~N}$ uptake among mesh core $\times$ fertilization combinations. Among nonfertilized plants in roots + hyphae and hyphae-intact, ${ }^{15} \mathrm{~N}$ atom $\%$ excess increased significantly after week 1 . Their fertilized counterparts showed only slight increases in leaf ${ }^{15} \mathrm{~N}$ atom $\%$ excess. In hyphae-rotated, leaf ${ }^{15} \mathrm{~N}$ atom $\%$ excess levels were lowest and remained unaffected by mesh core treatment regardless of fertilization. These relative differences in leaf ${ }^{15} \mathrm{~N}$ atom $\%$ excess became apparent among mesh core treatments starting 1 week after labeling and remained consistent throughout the study.

On the final sampling interval, when plant tissues were analyzed separately, we found similar mesh core treatment effects on ${ }^{15} \mathrm{~N}$ atom $\%$ excess in both leaves and stems (Table 1). ${ }^{15} \mathrm{~N}$ atom\% excess was highest in the leaves and stems of plants in roots + hyphae (Table 3 ). In addition to significantly higher ${ }^{15} \mathrm{~N}$ atom $\%$ excess, plants in roots + hyphae also had significantly higher leaf total N $(68.09 \mathrm{mg}$, $n=8)$ than those in both the hyphae-intact and hyphaerotated treatments (51.07 and $44.42 \mathrm{mg}$, respectively; $n=8$ ).

Nonfertilized plants in both roots + hyphae and hyphaeintact had significantly higher leaf and stem ${ }^{15} \mathrm{~N}$ atom $\%$ excess, relative to nonfertilized plants in hyphae-rotated (Table 3). Nonfertilized plants in hyphae-intact had approx- 


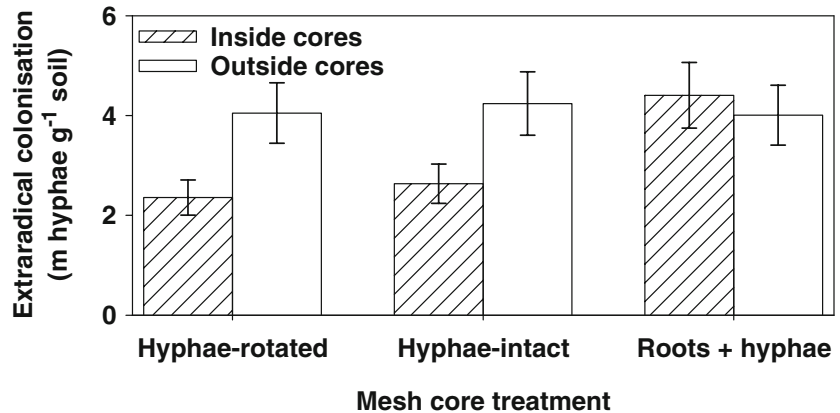

Fig. 2 Effect of mesh core treatment on extraradical colonization of soil inside and outside the mesh cores, from soils harvested 42 days after adding ${ }^{15} \mathrm{~N}$-labeled legume residue to the cores. Each column is the mean of eight observations summed across fertilized and nonfertilized plants. Error bars are 95\% confidence intervals; columns with overlapping confidence intervals are not significantly different at $p \leq 0.05$ (Tukey's test)

imately threefold higher total ${ }^{15} \mathrm{~N}$ and $\%$ NDFL in leaves and stems, and root access further doubled these variables. Fertilized plants in roots + hyphae and hyphae-intact had significantly less ${ }^{15} \mathrm{~N}$ atom\% excess than their nonfertilized counterparts (Table 3). Fertilization was also associated with significantly lower leaf and stem total ${ }^{15} \mathrm{~N}$ and $\%$ NDFL for plants in roots + hyphae and significantly lower leaf and stem \%NDFL for plants in hyphae-intact. Not surprisingly, fertilization had no effect on ${ }^{15} \mathrm{~N}$ of plants in hyphae-rotated, the treatment that had the lowest values for ${ }^{15} \mathrm{~N}$ atom $\%$ excess, total ${ }^{15} \mathrm{~N}$, and $\% \mathrm{NDFL}$ in all tissues.

${ }^{15} \mathrm{~N}$ status of roots was unaffected by mesh core treatment and fertilization (Tables 1 and 3). Plants that captured the most ${ }^{15} \mathrm{~N}$, the nonfertilized plants in roots + hyphae, contained $0.96 \mathrm{mg}$ (summed over leaves, stems, and roots; $n=4$ ) of the $9.09 \mathrm{mg}{ }^{15} \mathrm{~N}$ added to each core.

On the final sampling interval, 42 days after addition of the residue, ${ }^{15} \mathrm{~N}$ atom\% excess of residue inside the cores did not differ significantly among mesh core treatments $(p=$ $0.6)$ or with fertilization ( $p=0.4 ; 3.43$ atom $\%$ excess averaged across mesh core treatments and fertilization

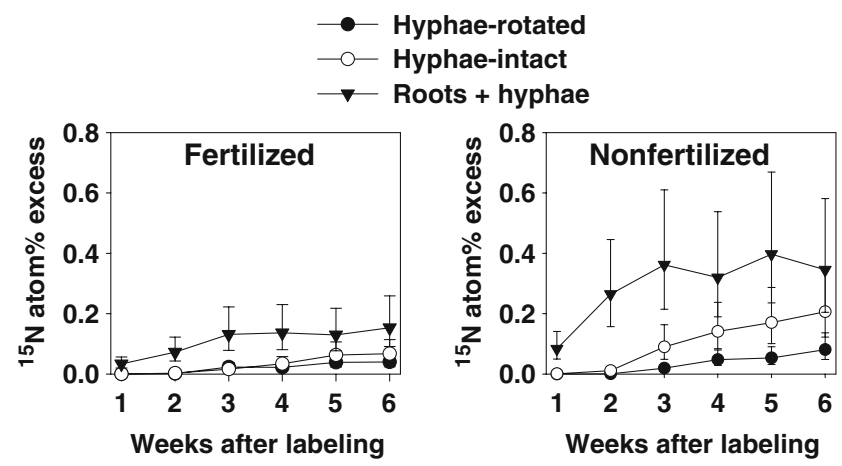

Fig. 3 Effects of mesh core treatment and fertilization on ${ }^{15} \mathrm{~N}$ atom $\%$ excess in leaves 1 to 6 weeks after adding ${ }^{15} \mathrm{~N}$-labeled legume residue to the cores. Each point is the mean of four observations. Error bars are $95 \%$ confidence intervals; columns with overlapping confidence intervals are not significantly different at $p \leq 0.05$ (Tukey's test) treatments, $n=24$ ). There was slight ${ }^{15} \mathrm{~N}$ enrichment of soil outside the cores based on values ranging from $0.002 \%$ to $0.01 \%$. This indicated minimal movement of ${ }^{15} \mathrm{~N}$ through mass flow, but there were no significant differences in soil ${ }^{15} \mathrm{~N}$ outside the cores among mesh core treatments $(p=0.4)$ or with fertilization $(p=0.5)$.

Soil mineral nutrition

Soil $\mathrm{NH}_{4}^{+}-\mathrm{N}$ and $\mathrm{NO}_{3}^{-}-\mathrm{N}$ and Olsen-P varied among mesh core treatments, depending on location (significant location $\times$ mesh core treatment interactions of $p=0.004, p<$ 0.0001 , and $p=0.001$, respectively). Mesh core treatment had no effect on soil $\mathrm{NH}_{4}^{+}-\mathrm{N}$ and $\mathrm{NO}_{3}^{-}-\mathrm{N}$ or Olsen-P outside the cores (data not shown), which is as expected, given that mesh core treatment also had no effect on root biomass (Table 1) or extraradical colonization (Fig. 2) outside the cores. In contrast, the presence of hyphae inside the cores and, especially, roots and hyphae were associated with significantly higher soil $\mathrm{NH}_{4}^{+}-\mathrm{N}$ inside hyphae-intact $\left(1.2 \mu \mathrm{g} \mathrm{g}^{-1}\right)$ and roots + hyphae cores $\left(1.4 \mu \mathrm{g} \mathrm{g}^{-1}\right)$, relative to hyphae-rotated cores $\left(0.9 \mu \mathrm{g} \mathrm{g}^{-1}\right)$. Significantly lower $\mathrm{NO}_{3}^{-}-\mathrm{N}$ and Olsen-P inside the roots + hyphae cores $\left(0.5 \mu \mathrm{g} \mathrm{g}^{-1}\right.$ and $18.2 \mu \mathrm{g} \mathrm{g}^{-1}$, respectively), and to levels as low as those outside all cores $\left(0.5 \mu \mathrm{g} \mathrm{g}^{-1}\right.$ and $18.2 \mu \mathrm{g} \mathrm{g}^{-1}$, respectively), indicated that mycorrhizal roots, but not hyphae alone, absorbed a substantial portion of $\mathrm{NO}_{3}^{-}-\mathrm{N}$ and $\mathrm{P}$. $\mathrm{NH}_{4}^{+}-\mathrm{N}, \mathrm{NO}_{3}^{-}-\mathrm{N}$, and $\mathrm{X}-\mathrm{K}$ were unaffected by fertilization ( $p=0.7, p=0.3$, and $p=0.3$, respectively). Fertilization affected Olsen-P, which was higher in soils of nonfertilized (22.01 $\left.\mu \mathrm{g} \mathrm{g}^{-1}, n=24\right)$ than fertilized plants (20.04 $\left.\mu \mathrm{g} \mathrm{g}^{-1}, n=24, p=0.03\right)$. There were no significant main or interaction effects on X-K $\left(2.31 \mu \mathrm{mol} \mathrm{g}{ }^{-1}, n=48\right)$.

\section{Discussion}

Fertilization effects on $\mathrm{N}$ capture

Mineral fertilization benefited both the host, in terms of biomass and total $\mathrm{N}$, and the AM fungus, in terms of intraradical colonization. Our finding of increased intraradical colonization in response to mineral fertilization is consistent with that of Hawkins and George (1999) and Hawkins et al. (2000), who found higher intraradical colonization of Triticum aestivum L. (wheat) with $\mathrm{N}$ applications. It appears that the dilute Hoagland's solution applied to our fertilized plants was not so high as to negatively affect the AM fungus, and this finding suggests that biomass of both the grapevine and the AM fungus, when grown in low fertility soil, benefit from moderate rates of mineral fertilization. Although our hyphae-rotated treatment was not $100 \%$ effective at preventing hyphal 
Table 3 AMF and plant responses to mesh core treatments with or without fertilization

\begin{tabular}{|c|c|c|c|c|c|c|}
\hline \multirow[t]{2}{*}{ Variable } & \multicolumn{3}{|c|}{ Fertilized plants } & \multicolumn{3}{|c|}{ Nonfertilized plants } \\
\hline & $\begin{array}{l}\text { Hyphae- } \\
\text { rotated }\end{array}$ & $\begin{array}{l}\text { Hyphae- } \\
\text { intact }\end{array}$ & $\begin{array}{l}\text { Roots + } \\
\text { Hyphae }\end{array}$ & $\begin{array}{l}\text { Hyphae- } \\
\text { rotated }\end{array}$ & $\begin{array}{l}\text { Hyphae- } \\
\text { intact }\end{array}$ & $\begin{array}{l}\text { Roots }+ \\
\text { Hyphae }\end{array}$ \\
\hline \multicolumn{7}{|l|}{ AMF colonization } \\
\hline $\begin{array}{l}\text { Extraradical hyphae } \\
\text { inside cores }\left(\mathrm{m} \mathrm{g}^{-1} \text { soil) }\right.\end{array}$ & $2.22 b$ & $2.69 b$ & $4.56 \mathrm{a}$ & $2.50 \mathrm{~b}$ & $2.58 \mathrm{~b}$ & $4.26 \mathrm{a}$ \\
\hline \multicolumn{7}{|l|}{ Plant ${ }^{15} \mathrm{~N}$ status } \\
\hline Leaf & $0.04 \mathrm{~b}$ & $0.07 \mathrm{ab}$ & $0.16 \mathrm{a}$ & $0.08 \mathrm{c}$ & $0.22 \mathrm{~b}^{\mathrm{a}}$ & $0.35 \mathrm{a}^{\mathrm{a}}$ \\
\hline Stem & $0.08 \mathrm{~b}$ & $0.10 \mathrm{~b}$ & $0.17 \mathrm{a}$ & $0.07 \mathrm{c}$ & $0.20 \mathrm{~b}^{\mathrm{a}}$ & $0.33 \mathrm{a}^{\mathrm{a}}$ \\
\hline Root & $0.21 \mathrm{a}$ & $0.21 \mathrm{a}$ & $0.21 \mathrm{a}$ & $0.20 \mathrm{a}$ & $0.33 \mathrm{a}$ & $0.25 \mathrm{a}$ \\
\hline \multicolumn{7}{|l|}{ Total ${ }^{15} \mathrm{~N}\left(\mathrm{mg}\right.$ plant $\left.{ }^{-1}\right)$} \\
\hline Leaf & $0.02 b$ & $0.04 \mathrm{~b}$ & $0.12 \mathrm{a}$ & $0.03 \mathrm{c}$ & $0.09 \mathrm{~b}$ & $0.21 \mathrm{a}^{\mathrm{a}}$ \\
\hline Stem & $0.12 b$ & $0.15 b$ & $0.27 \mathrm{a}$ & $0.09 \mathrm{c}$ & $0.24 b$ & $0.57 \mathrm{a}^{\mathrm{a}}$ \\
\hline Root & $0.23 \mathrm{a}$ & $0.25 \mathrm{a}$ & $0.24 \mathrm{a}$ & $0.14 \mathrm{a}$ & $0.29 \mathrm{a}$ & $0.18 \mathrm{a}$ \\
\hline \multicolumn{7}{|l|}{$\%$ NDFL } \\
\hline Leaf & $0.80 \mathrm{~b}$ & $1.36 \mathrm{~b}$ & $3.10 \mathrm{a}$ & $1.61 \mathrm{c}$ & $4.19 \mathrm{~b}^{\mathrm{a}}$ & $6.93 \mathrm{a}^{\mathrm{a}}$ \\
\hline Stem & $1.56 \mathrm{~b}$ & $1.98 \mathrm{ab}$ & $3.37 \mathrm{a}$ & $1.47 \mathrm{c}$ & $3.90 \mathrm{~b}^{\mathrm{a}}$ & $6.49 \mathrm{a}^{\mathrm{a}}$ \\
\hline Root & $4.11 \mathrm{a}$ & $4.18 \mathrm{a}$ & $4.17 \mathrm{a}$ & $3.94 \mathrm{a}$ & $6.55 \mathrm{a}$ & $4.91 \mathrm{a}$ \\
\hline
\end{tabular}

Means $(n=4)$ followed by different letters in the same row and fertilization treatment are significantly different at $p \leq 0.05$, Tukey's test $\%$ NDFL Percentage $\mathrm{N}$ in plant tissues derived from the legume residue

${ }^{a}$ Significantly higher than that of fertilized plants of the same mesh core treatment

proliferation in the residue, the lack of a change in ${ }^{15} \mathrm{~N}$ atom $\%$ excess in leaves collected weekly following addition of the residue suggests that frequent rotation of these cores did limit hyphal transfer of ${ }^{15} \mathrm{~N}$ to the plants.

Fertilization-associated increases in plant biomass and intraradical colonization were not met with increased uptake of ${ }^{15} \mathrm{~N}$ from the legume crop residue. Instead, fertilized plants took up approximately threefold less $\mathrm{N}$ from the residue than did nonfertilized plants. Given that fertilized plants received approximately five times more $\mathrm{N}$, all in the form of $\mathrm{KNO}_{3}$ and $\mathrm{Ca}\left(\mathrm{NO}_{3}\right)_{2}$, we expect that $\mathrm{N}$ demand of nonfertilized plants was substantially higher upon addition of the residue, as this was their only supplemental nutrition. However, extraradical colonization inside the cores did not change with fertilization, despite significant decreases in hyphal uptake of ${ }^{15} \mathrm{~N}$ from the cores of the hyphae-intact treatment. Therefore, it seems likely that some mechanism other than reduced $\mathrm{C}$ allocation from the host to the fungus was responsible. Fertilizationassociated reduction in hyphal ${ }^{15} \mathrm{~N}$ capture in the absence of changes in extraradical colonization have also been documented by Johansen et al. (1994), who hypothesized that ${ }^{15} \mathrm{~N}$ uptake by the extraradical hyphae and/or subsequent transfer to the host was, somehow, regulated by the roots. In the monoxenic Daucus carota-Glomus intraradices study system, expression of the phosphate transporter, GiPT, increased within root-distant extraradical hyphae in response to high concentrations of $\mathrm{N}$ supplied only to the roots (Olsson et al. 2005), demonstrating that expression of genes involved with hyphal uptake of soilderived nutrients are regulated by roots.

It is possible that fertilization encouraged different AMF species, such that those of nonfertilized plants had higher ${ }^{15} \mathrm{~N}$ absorption per unit hyphae than those of fertilized plants. Fertilization caused shifts in AMF species composition in grasslands (Jumpponen et al. 2005), tropical forests (Treseder and Allen 2002), and coastal sage scrub communities (Egerton-Warburton and Allen 2000). It is conceivable that AMF composition affects $\mathrm{N}$ uptake, given that AMF species have been shown to differ in their ability to form common mycorrhizal networks (Avio et al. 2006) and in rate of $\mathrm{N}$ (Hawkins et al. 2000) and P (Cavagnaro et al. 2005) uptake by their extraradical hyphae. However, given the single source of inoculum for all plants and the relatively short time frame of the study, it seems unlikely that significant AMF species shifts occurred due to fertilization, let alone contributed to reduced hyphal ${ }^{15} \mathrm{~N}$ uptake.

Impacts of hyphal $\mathrm{N}$ capture on host $\mathrm{N}$ nutrition

A positive correlation between extraradical colonization of labeled organic matter and plant ${ }^{15} \mathrm{~N}$ suggests that capture of $\mathrm{N}$ from organic matter by root-distant hyphae may sometimes contribute to host $\mathrm{N}$ nutrition (Hodge et al. 2001). We found that hyphal proliferation in the residue tripled the percentage of leaf and stem $\mathrm{N}$ derived from the residue (albeit only in the absence of fertilization). 
However, increases in ${ }^{15} \mathrm{~N}$ among plants with only hyphal access to the residue were not met with significant increases in host $\mathrm{N}$. In contrast, increases in ${ }^{15} \mathrm{~N}$ uptake with mycorrhizal root proliferation in the residue were accompanied by significant increases in leaf total N. Proliferation in the residue by mycorrhizal roots was also associated with similar levels of soil $\mathrm{NO}_{3}^{-}-\mathrm{N}$ and Olsen-P inside the cores as outside the cores of all mesh core treatments, suggesting that uptake of soil $\mathrm{N}$ and $\mathrm{P}$ from inside the cores was significantly impacted by roots but not by hyphae alone. This finding is in agreement with previous research showing a lack of significant host $\mathrm{N}$ increases with $\mathrm{N}$ supplied to extraradical hyphae and not to host roots (Ames et al. 1983; Cheng and Baumgartner 2004a, 2006; Hodge 2001; Hodge et al. 2001; Johansen et al. 1992; Olsson et al. 2005). Our finding that roots may be more important than hyphae alone at exploiting $\mathrm{N}$ from organic matter is supported by similar findings in other hosts (e.g., Hodge 2003). Significant decreases in $\mathrm{NO}_{3}^{-}-\mathrm{N}$ in the roots + hyphae cores and outside the mesh cores of all treatments support previous work demonstrating that $\mathrm{NO}_{3}^{-}$is preferred over $\mathrm{NH}_{4}^{+}$by grapevine roots (Mullins et al. 1992).

\section{Conclusion}

Based on quantification of intraradical colonization, extraradical colonization, ${ }^{15} \mathrm{~N}$ content of host tissue, host biomass, and soil $\mathrm{N}, \mathrm{P}$, and $\mathrm{K}$ concentrations, we demonstrated that mineral fertilization limited $\mathrm{N}$ uptake from legume crop residue by AMF hyphae and mycorrhizal roots. Our findings suggest that even low rates of fertilizer, which are typical of winegrape production, may be incompatible with legume crop incorporation with respect to both AMF-mediated $\mathrm{N}$ capture and root uptake of $\mathrm{N}$. If organic matter is used as a primary means of modifying soil fertility, as in organic vineyards where mineral fertilizers are forbidden, it may be important to incorporate the material into vineyard soil with the highest root densities (i.e., as close to the vine trunks as possible), given our finding that roots had a dominant role over hyphae in $\mathrm{N}$ uptake. Our somewhat contradictory findings regarding fertilization effects on different AMF parameters (i.e., increased intraradical colonization, no effect on extraradical colonization, and decreased hyphal capture of ${ }^{15} \mathrm{~N}$ ) highlight the need for comprehensive evaluation of AMF parameters when testing the effects of farming practices on mycorrhizae.

Acknowledgements We thank Bruce Mackey [Pacific West Area Statistician, United States Department of Agriculture-Agricultural Research Service (USDA-ARS), Albany, CA, USA] for advice on experimental design and means comparisons. Paul Schreiner (USDAARS, Corvallis, OR, USA), Kerri Steenwerth (USDA-ARS, Davis,
CA, USA), Louise Jackson (Department. of Plant Sciences, University of California, Davis, CA, USA), and Alison Bennett (Department of Evolution and Ecology, University of California, Davis, CA, USA) provided helpful comments on this manuscript. Research was supported by USDA-ARS.

\section{References}

Allen MF (1991) The Ecology of Mycorrhizae. Cambridge University Press, Cambridge, UK

Ames RN, Reid CPP, Porter LK, Cambardella C (1983) Hyphal uptake and transport of nitrogen from two ${ }^{15} \mathrm{~N}$-labelled sources of Glomus mosseae, a vesicular-arbuscular mycorrhizal fungus. New Phytol 95:381-396

Avio L, Pellegrino E, Bonari E, Giovannetti M (2006) Functional diversity of arbuscular mycorrhizal fungal isolates in relation to extraradical mycelial networks. New Phytol 172:347-357

Biricolti S, Ferrini F, Rinaldelli E, Tamantini I, Vignozzi N (1997) VAM fungi and soil lime content influence rootstock growth and nutrient content. Amer J Enol Vitic 48:93-99

Boddington CL, Bassett EE, Jakobsen I, Dodd JC (1999) Comparison of techniques for the extraction and quantification of extra-radical mycelium of arbuscular mycorrhizal fungi in soils. Soil Biol Biochem 31:479-482

Cavagnaro TR, Smith FA, Smith SE, Jakobsen I (2005) Functional diversity of arbuscular mycorrhizae: exploitation of soil patches with different phosphate enrichment differs among fungal species. Plant Cell Environ 28:642-650

Cheng X, Baumgartner K (2004a) Arbuscular mycorrhizal fungimediated nitrogen transfer from vineyard cover crops to grapevines. Biol Fertil Soils 40:406-412

Cheng X, Baumgartner K (2004b) Survey of arbuscular mycorrhizal fungal communities in Northern California vineyards and mycorrhizal colonization potential of grapevine nursery stock. HortScience 39:1702-1706

Cheng X, Baumgartner K (2006) Effects of mycorrhizal roots and extraradical hyphae on ${ }^{15} \mathrm{~N}$ uptake from vineyard cover crop litter and the soil microbial community. Soil Biol Biochem 38:26652675

Deal DR, Boothroyd CW, Mai WF (1971) Replanting of vineyards and its relationship to vesicular-arbuscular mycorrhiza. Phytopathology 62:172-175

Egerton-Warburton LM, Allen EB (2000) Shifts in arbuscular mycorrhizal communities along an anthropogenic nitrogen deposition gradient. Ecol Appl 10:484-496

Eissenstat DM (1992) Costs and benefits of constructing roots of small diameter. J Plant Nutrition 15:763-782

Epstein E (1972) Mineral Nutrition of Plants: Principles and Perspective. John Wiley \& Sons, New York, NY

Giovannetti M, Mosse B (1980) An evaluation of techniques for measuring vesicular arbuscular mycorrhizal infection in roots. New Phytol 84:489-500

Gryndler M, Larsen J, Hrselova H, Rezacova V, Gryndlerova H, Kubat J (2006) Organic and mineral fertilization, respectively, increase and decrease the development of external mycelium of arbuscular mycorrhizal fungi in a long-term field experiment. Mycorrhiza 16:159-166

Hawkins H-J, George E (1999) Effect of plant nitrogen status on the contribution of arbuscular mycorrhizal hyphae to plant nitrogen uptake. Physiol Plant 105:694-700

Hawkins H-J, Johansen A, George E (2000) Uptake and transport of organic and inorganic nitrogen by arbuscular mycorrhizal fungi. Plant Soil 226:275-285 
Hodge A (2001) Arbuscular mycorrhizal fungi influence decomposition of, but not plant nutrient capture from, glycine patches in soil. New Phytol 151:725-734

Hodge A (2003) N capture by Plantago lanceolata and Brassica napus from organic matter: the influence of spatial dispersion, plant competition and an arbuscular mycorrhizal fungus. J Exp Botany 54:2331-2342

Hodge A, Campbell CD, Fitter AH (2001) An arbuscular mycorrhizal fungus accelerates decomposition and acquires nitrogen directly from organic material. Nature 413:297-299

Ingels CA, Scow KM, Whisson DA, Drenovsky RE (2005) Effects of cover crops on grapevines, yield, juice composition, soil microbial ecology, and gopher activity. Amer J Enol Vitic 56:19-29

Jakobsen I, Abbott LK, Robson AD (1992) External hyphae of vesicular-arbuscular mycorrhizal fungi associated with Trifolium subterraneum L. 1. Spread of hyphae and phosphorus inflow into roots. New Phytol 120:371-380

Jin H, Pfeffer PE, Douds DD, Piotrowski E, Lammers PJ, ShacharHill Y (2005) The uptake, metabolism, transport and transfer of nitrogen in an arbuscular mycorrhizal symbiosis. New Phytol 168:687-696

Johansen A, Jakobsen I, Jensen ES (1992) Hyphal transport of ${ }^{15} \mathrm{~N}$ labelled nitrogen by a vesicular-arbuscular mycorrhizal fungus and its affect on depletion on inorganic soil N. New Phytol 122:281-288

Johansen A, Jakobsen I, Jensen ES (1994) Hyphal N transport by a vesicular-arbuscular mycorrhizal fungus associated with cucumber grown at three nitrogen levels. Plant Soil 160:1-9

Johnson NC, Rowland DL, Corkidi L, Egerton-Warburton LM, Allen EB (2003) Nitrogen enrichment alters mycorrhizal allocation at five mesic to semiarid grasslands. Ecology 84:1895-1908

Jumpponen A, Trowbridge J, Mandyam K, Johnson L (2005) Nitrogen enrichment causes minimal changes in arbuscular mycorrhizal colonization but shifts community compositionevidence from rDNA data. Biol Fertil Soils 41:217-224

Koske RE, Gemma JN (1989) A modified procedure for staining roots to detect VA mycorrhizas. Mycol Res 92:486-505

Linderman RG, Davis EA (2001) Comparative response of selected grapevine rootstocks and cultivars to inoculation with different mycorrhizal fungi. Amer J Enol Vitic 52:8-11

Mäder P, Vierheileg H, Streitwolf-Engel R, Boller T, Frey B, Christie P, Wiemken A (2000) Transport of ${ }^{15} \mathrm{~N}$ from a soil compartment separated by a polytetrafluoroethylene membrane to plant roots via the hyphae of arbuscular mycorrhizal fungi. New Phytol 146:155-161

Matthews MA, Ishii R, Anderson MM, O’Mahony M (1990) Dependence of wine sensory attributes on vine water status. J Sci Food Agric 51:321-335

Menge JA, Raski DJ, Lider LA, Johnson ELV, Jones NO, Kissler JJ, Hemstreet CL (1983) Interactions between mycorrhizal fungi, soil fumigation, and growth of grapes in California. Amer J Enol Vitic 34:117-121

Miller RM, Reinhardt DR, Jastrow JD (1995) External hyphal production of vesicular-arbuscular mycorrhizal fungi in pasture and tallgrass prairie communities. Oecologia 103:17-23

Mullins MG, Bouquet A, Williams LE (1992) Biology of the Grapevine. Cambridge University Press, Cambridge, UK

Nappi P, Jodice R, Luzzati A, Corino L (1985) Grapevine root system and VA mycorrhizae in some soils of Piedmont (Italy). Plant Soil 85:205-210

Newman EI (1966) A method of estimating the total length of root in a sample. J Appl Ecol 3:139

Oehl F, Sieverding E, Ineichen K, Ris E-A, Boller T, Wiemken A (2005) Community structure of arbuscular mycorrhizal fungi at different soil depths in extensively and intensively managed agroecosystems. New Phytol 165:273-283

Olsson PA, Burleigh SH, van Aarle IM (2005) The influence of external nitrogen on carbon allocation to Glomus intraradices in monoxenic arbuscular mycorrhizae. New Phytol 168:677-686

Patrick AE, Smith R, Keck K, Berry AM (2004) Grapevine uptake of ${ }^{15} \mathrm{~N}$-labeled nitrogen derived from a winter-annual leguminous cover-crop mix. Amer J Enol Vitic 55:187-190

Patrick-King A, Berry AM (2005) Vineyard delta 15-N, nitrogen and water status in perennial clover and bunch grass cover crop systems of California's central valley. Agric Ecosyst Environ 109:262-272

Perret P, Weissenbach P, Schwager H, Heller WE, Koblet W (1983) Adaptive nitrogen-management: a tool for the optimization of $\mathrm{N}$ fertilization in vineyards. Vitic Enol Sci 48:124-126

Possingham JV, Groot-Obbink J (1971) Endotrophic mycorrhiza and the nutrition of grape vines. Vitis 10:120-130

Schreiner RP (2005) Spatial and temporal variation of roots, arbuscular mycorrhizal fungi, and plant and soil nutrients in a mature Pinot noir (Vitis vinifera L.) vineyard in Oregon, USA. Plant Soil 276:219-234

Schreiner RP, Bethlenfalvay GJ (2003) Crop residue and Collembola interact to determine the growth of mycorrhizal pea plants. Biol Fertil Soils 39:1-8

Schubert A, Cammarata S, Eynard I (1988) Growth and root colonization of grapevines inoculated with different mycorrhizal endophytes. Hortscience 23:302-303

St John TV, Coleman DC, Reid CPP (1983) Association of vesiculararbuscular mycorrhizal hyphae with soil organic particles. Ecology 64:957-959

Treseder KK (2004) A meta-analysis of mycorrhizal responses to nitrogen, phosphorus, and atmospheric $\mathrm{CO}_{2}$ in field studies. New Phytol 164:347-355

Treseder KK, Allen MF (2002) Direct nitrogen and phosphorus limitation of arbuscular mycorrhizal fungi: a model and field test. New Phytol 155:507-515 